\title{
Blue Ocean Leadership and Emotional Intelligence in Government Link Companies (GLCs): Preparing for Industry 4.0
}

\author{
Wan Noordiana Wan Hanafi ${ }^{1 *}$, Salina Daud ${ }^{2}$, and Nur Lyana Baharin ${ }^{3}$ \\ ${ }^{1}$ College of Graduate Studies, Universiti Tenaga Nasional, Jalan IKRAM - UNITEN, 43000 Kajang, \\ Selangor Darul Ehsan. \\ $2 \& 3$ College of Business Management and Accounting, Universiti Tenaga Nasional, Campus Sultan \\ Haji Ahmad Shah, 26700, Muadzam Shah, Pahang.
}

\begin{abstract}
This research is carried out to examine the influences of blue ocean leadership styles on emotional intelligence. A stratified random sampling technique is used to identify the sample for this study. Questionnaire is distributed to 120 middle to top level leaders from the selected government link companies (GLCs) which is listed in the Government Link Transformation Programme (GLTP). A partial least square structural model (PLS-SEM) approach is used to analyses the data for this study. The findings indicate that there is a significant relationship between blue ocean leadership style and emotional intelligence. This study would give practical implications where it could inform leaders that they need to have high emotional intelligence in order to lead the organization. This study also contributes to new knowledge by pointing to the leadership role of accurate attributions, where each attribution can lead to enhancing leader effectiveness.
\end{abstract}

\section{Introduction}

Industry 4.0 is becoming a top priority for many research centres, universities, and companies (Engelbertink \& Woudstra, 2017). Even, Malaysia Government through the National Transformation Plan 2050 (TN50) in shaping the future of Malaysian country for the year 2020 to 2050 through emphasizing on the value of high technology. However, industry 4.0 is blurring the boundaries between humans and technology, (Schwab, 2017). Due to the changes that brought through Industry 4.0 changes in management and leadership are required as, leaders need to be on the forefront of adapting to these changes (Weinmann, 2017). Other than that, the study on industry 4.0 is currently mainly focused on the technical and production areas but seldom look into the impact towards people (Feng, 2016). (Alhuraish, Robledo, \& Kobi, 2014; Poksinska, Swartling, \& Drotz, 2013) have identified that leadership are the most critical key factor during the change process. Besides that, (Tunçer, 2011) has also stated that, in order for an organization to adapt to changes, it is necessary for it to adopt an effective leadership approach. 
In this study, leadership is described in terms of blue ocean leadership styles, which were introduced by (Kim \& Mauborgne, 2014). Blue ocean leadership styles compromise of value innovation. Value innovation is something that is all about activities and strategies which companies try to achieve value and add value towards their leader, it not only incorporate through blue ocean strategy but it is also encourage to enhance leader through blue ocean leadership. As competition growth and also the pace of technological interversion speeds up, the task is not only providing new services and products, but additionally changing the nature of management inside organizations (Pisano \& Teece, 2007). Research by (Birkinshaw, Hamel, \& Mol, 2008) has certainly show how management innovation deliver potential advantages to it, but additionally redefine an industry by way of influencing the spread of new ideas. leadership would plays a vital function in organization' innovation, due to the fact leaders can introduce novel ideas into an organization, set up precise goals, and inspire innovation initiatives from subordinates (Noruzy, Dalfard, Azhdari, Nazari-Shirkouhi, \& Rezazadeh, 2013). Value innovation could be added towards leaders by bringing new thinking and different actions to how they could lead, manage, and think differently about their role and the challenges the organization faces.

As we are reworking in the direction of industry 4.0, it's far widely recognized that it will be influencing the working environments significantly [2]. Such situation could require employees to have skills which includes emotional intelligence (Group, 2017). It is similiar with finding by (Goleman, 1998), where powerful leaders will have a high degree of emotional intelligence (Rajah, Song, \& Arvey, 2011). Other research also supported the arguments that leadership is essentially an emotional process also supported the arguments that leadership is fundamentally an emotional process (Radhakrishnan \& UdayaSuriyan, 2010; Rehman, 2012). Study done by (2014), have suggests that further research needs to be achieved to expand the knowledge and information about the possible influences or outcomes of emotional intelligence may have on leadership as that could be a complex relationship that needs in addition validation. Aside from that, (Puteri Aishah, Abd Rahim, Ismail, \& Mariatul Shima, 2015) have also stated that emotional intelligence studies is relatively thin and the relationship between leadership and emotional intelligence is even smaller. consequently this study attempts to close the research gap by investigating the relationship between blue ocean leadership style and emotional intelligence among leaders at GLCs. 


\section{Literature review}

\subsection{Blue ocean leadership style}

Leadership is a definition that is used in building teams to make synergy and to be the ones on top. It is an important management tool as leaders work through people to generate greatest outcome for the organization with minimal inputs and resources. Besides, good leadership contributes to improve organizational effectiveness and performance (Riaz \& Haider, 2010). Possibly the most researched leadership theories over the past thirty years have been the transformational and transactional leadership theories (Latham, 2014). Transformational leadership idea is all about leadership that creates effective change within the followers whereby they take care of every other's interests and act within the interests of the organization as a whole (Van den Hurk, Hall-Mendelin, Johansen, Warrilow, \& Ritchie, 2012). Transactional leadership, are the positive effects of both of these theories on quality improvement and firm performance were confirmed by (2009). Different styles are needed for different working environments, as it may affect organizational effectiveness or performance (Nahavandi, 2006). For this study, blue ocean leadership styles which were introduced by (2014) will be use. Blue ocean leadership is a leadership style where its focus is to achieve an organizational increase in leadership strength quickly and at low cost, which translates into high performance for the business (Kim \& Mauborgne, 2017).

The key difference between other leadership approaches and the blue ocean leadership styles is as present in table 1 below:

Table 1 : Comparison between conventional and blue ocean leadership style

\begin{tabular}{|l|l|}
\hline \multicolumn{1}{|c|}{ Conventional Leadership Style } & \multicolumn{1}{|c|}{ Blue Ocean Leadership Style } \\
\hline $\begin{array}{l}\text { Focuses on the values, qualities and } \\
\text { behavioural styles }\end{array}$ & $\begin{array}{l}\text { Focuses on what acts and activities leaders need } \\
\text { to undertake, not on who leaders need to be. }\end{array}$ \\
\hline $\begin{array}{l}\text { Tends to be quite generic and is often } \\
\text { detached from what organizations stand } \\
\text { for }\end{array}$ & $\begin{array}{l}\text { Connects leaders' actions closely to market } \\
\text { realities }\end{array}$ \\
\hline $\begin{array}{l}\text { Focuses mostly on the executive and senior } \\
\text { levels }\end{array}$ & $\begin{array}{l}\text { Distributes leadership across all three } \\
\text { management levels }\end{array}$ \\
\hline Invests extra time for leadership practices & $\begin{array}{l}\text { Pursues high impact leadership acts and activities } \\
\text { at low cost }\end{array}$ \\
\hline
\end{tabular}




\subsection{Emotional intelligence}

Emotional intelligence is about understanding and accepting emotions when they deliver something. Through emotional intelligence, leaders will gain incredible value from emotions which could help leaders to make better decisions that can develop a real selfefficacy (Radhakrishnan \& UdayaSuriyan, 2010). This could help leader to take advantage of their emotions and use them to predict major improvements in organizational through interpersonal relationships (Gardner \& Stough, 2002). Emotional intelligence has become an interesting topic for discussion among researchers for many years (López-Domínguez, Enache, Sallan, \& Simo, 2013). People have also theorized that emotional intelligence contributes to people's capacity to work effectively in teams, manage stress, and/or lead others (Butler \& Chinowsky, 2006; Conte, 2005; Hopkins, O'Neil, \& Williams, 2007). Bass and Stogdill (1990)found an association between emotional maturity, managerial effectiveness and managerial development.

\subsection{Blue ocean leadership style and emotional intelligence}

Research have proven useful link among emotional intelligence and leaders within the workplace, (Barbuto \& Burbach, 2006; Rosete \& Ciarrochi, 2005; Sy, Tram, \& O'Hara, 2006; Wong \& Law, 2002). Where the integration of the cognitive and emotional component could led to better decision making as leaders approach the problems more holistically (Rajah et al., 2011). Other than that, emotional intelligence was found to an important factor in creating a successful work environment (Cross \& Travaglione, 2003). A number of studies (Barbuto \& Burbach, 2006; Rosete \& Ciarrochi, 2005; Sy et al., 2006) empirically test the positive association between leadership and emotional intelligence, which generally supported the view that emotional intelligence is an essential determinant for managerial effectiveness and performance. Other studies supported the arguments that leadership is intrinsically an emotional process (Rehman, 2012; Singh \& Krishnan, 2008), and (Anand \& UdayaSuriyan, 2010) on the other hand has also discovered that leadership practices of executives are significantly related to emotional intelligence. While other studies ignored the role of emotions in leadership processes.

From the literature above, the following hypothesis is propose:

H1: There is a significant effects of blue ocean leadership styles and emotional intelligence.

\section{Methodology}

Sample for this study were selected using stratified random sampling. This study adopted survey method, which is a quantitative study in nature. The questions for blue ocean leadership styles was adopted from (2016) with a total of 73 questions, and for emotional intelligence emotional quotient inventory (EQ-i) by (Lee, 2014) which consist of 25 questions. Questions were administrated to 120 respondents range from middle to top level managers in Government Link Companies (GLCs). However, only 55 questions were returned. The respondents were asked to rate each item on a five-point Likert scale, ranging from strongly agree to strongly disagree. Data were analyzes using Partial Least Square Structural Equation Model (PLS-SEM) approach. Two step approach by Anderson and Gerbing (1988) where used, which is done by assessing the measurement model and the structural equation model. 


\section{Result and Discussion}

\subsection{Descriptive analysis}

Questionnaire were distributed to 120 respondents, however, from 120 only 55 questionnaire were returned. Therefore, 55 respondent were used for the data analysis, yielding to $64 \%$ of response rate. From 55 respondent, most of the respondent are Malaysian with $90.9 \%$. For gender, majority of the respondent in this study were female with $61.8 \%$ and male with $38.2 \%$. Average age of the respondent were ranged from 31-40 years with $49.1 \%$ and $34.5 \%$ for $20-30$ years old. In term of race, highest number of respondents are Malay with $65.6 \%$. As for marital status, majority of the respondent were married $60.2 \%$. For education level, $69.1 \%$ of the respondent have a bachelor degree, $23.6 \%$ with master degree and $7.3 \%$ with STPM. For job position, highest number of respondents are from the executive level with $61.8 \%$. In terms of years of working in the organization, $72.7 \%$ of the respondent have been working in the organization for less than 5 years. Lastly, for number of years working in the industry, highest number of respondents are for less than 5 years with $50.9 \%$.

\subsection{Measurement model analysis}

Measurement model is focusing on the assessment of the validity and reliability of the constructs within the model. From figure 1 below, blue ocean leadership styles and emotional intelligence had been conceptualized as a second-order constructs. therefore, we followed the approach recommended within the literature in PLS that is the repeated indicator method to model the second-order factors in the PLS analysis (Hair, Hult, \& Ringle, 2014). Reliability for this study is examine using composite reliability (CR). As found in Table 2 below, all constructs exhibited CR, extra than the minimum acceptable level of 0.70 (Fornell \& Larcker, 1981; Nunnally \& Bernstein, 1994).

Next are, data validity of the measurement model. it is verify primarily based on its convergent and discriminant validity of the variables (Chin, 2010). Convergent validity of the size is established, if the variance extracted value is more than 0.50 (Fornell \& Larcker, 1981). As for the discriminant validity, it focuses on the degree in which the item of a latent variable differs from each other (Johnson \& Christensen, 2008) recommended using Fornell and Larckers, in which it was examined through evaluating the correlations and the square root of the average variance extracted (AVE) for that construct (Mageswari, Sivasubramanian, \& Dath, 2015). As can be seen from Table 3, all the square root of the AVE was higher than the correlations values in the row. 


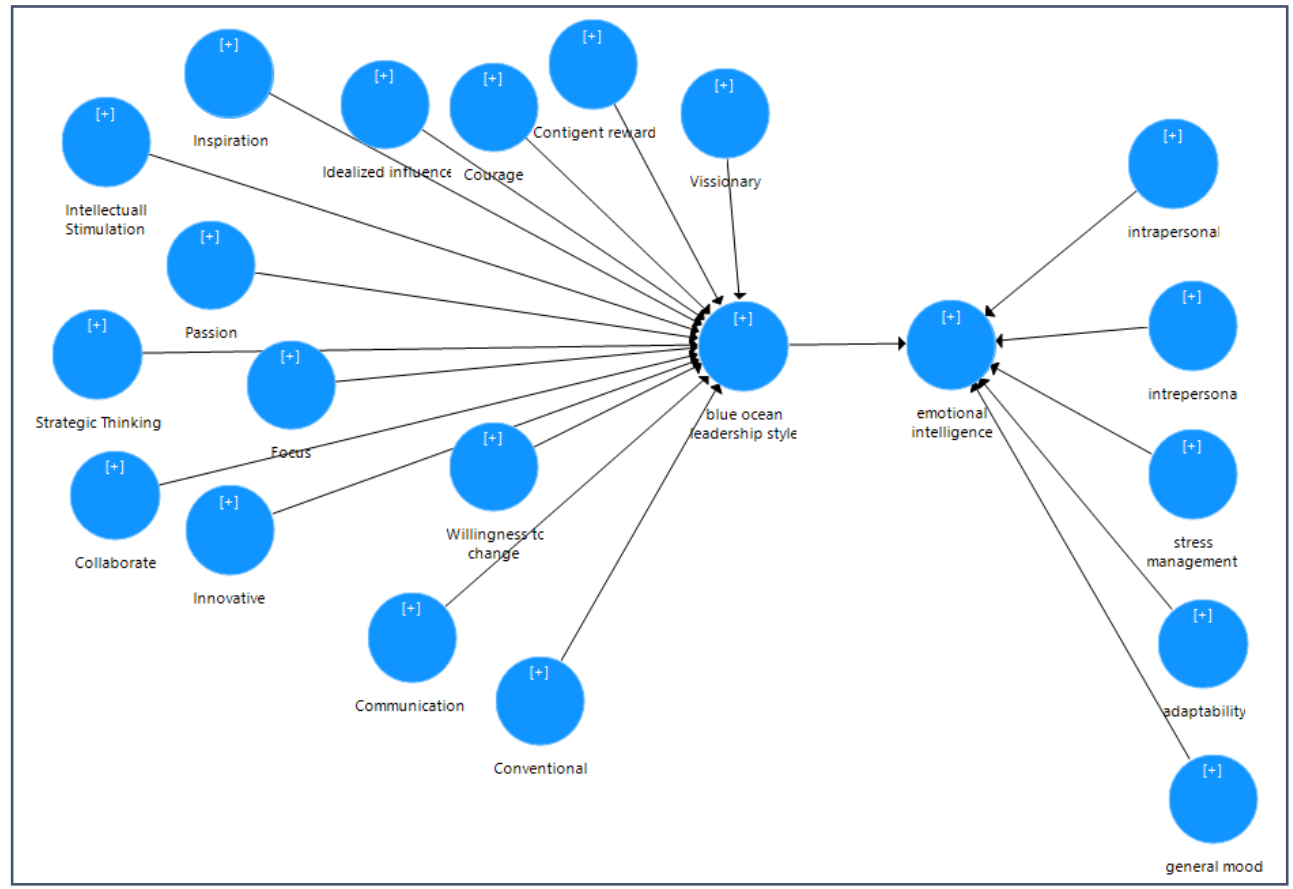

Figure 1: Path coefficient

Table 2: Validity and Reliability

\begin{tabular}{|c|c|c|c|c|c|}
\hline $\begin{array}{c}\text { First order } \\
\text { construct }\end{array}$ & $\begin{array}{l}\text { Second order } \\
\text { construct }\end{array}$ & & Loadings & CR & $\begin{array}{l}\text { AVE } \\
>0.5\end{array}$ \\
\hline Visionary & & $\begin{array}{ll}\text { V1 } & 0.684 \\
\text { V2 } & 0.692 \\
\text { V3 } & 0.752 \\
\end{array}$ & $\begin{array}{l}\text { V4 } 0.716 \\
\text { V5 } 0.716\end{array}$ & 0.931 & 0.731 \\
\hline $\begin{array}{l}\text { Contingent } \\
\text { reward }\end{array}$ & & $\begin{array}{l}\text { CR6 } 0.698 \\
\text { CR7 } 0.526\end{array}$ & 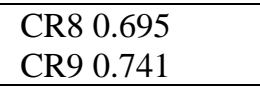 & 0.880 & 0.649 \\
\hline Courage & & $\begin{array}{ll}\text { C10 } & 0.643 \\
\text { C11 } & 0.632 \\
\text { C12 } & 0.747 \\
\end{array}$ & & 0.949 & 0.860 \\
\hline $\begin{array}{l}\text { Idealized } \\
\text { influences }\end{array}$ & & $\begin{array}{l}\text { II13 } 0.571 \\
\text { II14 } 0.752\end{array}$ & $\begin{array}{l}\text { II15 } 0.769 \\
\text { II16 } 0.608\end{array}$ & 0.902 & 0.698 \\
\hline Inspiration & & $\begin{array}{ll}\text { I17 } & 0.641 \\
\text { I18 } & 0.729 \\
\end{array}$ & $\begin{array}{ll}\text { I19 } & 0.663 \\
\text { I20 } & 0.684\end{array}$ & 0.927 & 0.761 \\
\hline $\begin{array}{l}\text { Intellectual } \\
\text { stimulation }\end{array}$ & & $\begin{array}{l}\text { IS21 } 0.819 \\
\text { IS22 } 0.801\end{array}$ & IS23 0.853 & 0.938 & 0.836 \\
\hline Passion & & $\begin{array}{l}\text { P24 } 0.625 \\
\text { P25 } 0.788\end{array}$ & P26 0.703 & 0.914 & 0.779 \\
\hline $\begin{array}{l}\text { Strategic } \\
\text { thinking }\end{array}$ & & $\begin{array}{ll}\text { ST27 } & 0.836 \\
\text { ST28 } & 0.761 \\
\text { ST29 } & 0.648 \\
\end{array}$ & $\begin{array}{lll}\text { ST30 } & 0.763 \\
\text { ST31 } & 0.775 \\
\end{array}$ & 0.910 & 0.670 \\
\hline Focus & & $\begin{array}{ll}\text { F32 } & 0.634 \\
\text { F33 } & 0.619 \\
\end{array}$ & $\begin{array}{cc}\text { F35 } & 0.609 \\
\text { F36 } & 0.724 \\
\end{array}$ & 0.916 & 0.685 \\
\hline
\end{tabular}




\begin{tabular}{|c|c|c|c|c|c|c|}
\hline & & \multicolumn{3}{|c|}{ F34 0.659} & & \\
\hline Collaborate & & \multicolumn{3}{|c|}{$\begin{array}{ll}\text { CLBRTE37 } & 0.637 \\
\text { CLBRTE38 } & 0.624 \\
\text { CLBRTE40 } & 0.612 \\
\end{array}$} & 0.898 & 0.747 \\
\hline Innovate & & \multicolumn{3}{|c|}{$\begin{array}{lll}\text { INVTE41 } & 0.563 & \text { INVTE44 } \\
0.559 & & \\
\text { INVTE42 } & 0.501 & \text { INVTE45 } \\
0.689 & & \\
\text { INVTE43 } & 0.627 & \text { INVTE46 } \\
0.644 & & \\
\end{array}$} & 0.937 & 0.712 \\
\hline $\begin{array}{l}\text { Willingness to } \\
\text { change }\end{array}$ & & \multicolumn{3}{|c|}{$\begin{array}{lll}\text { WTC47 } & 0.66 & \text { WTC49 } \\
0.787 & & \\
\text { WTC48 } & 0.725 & \\
\end{array}$} & 0.892 & 0.734 \\
\hline Communication & & \multicolumn{3}{|c|}{$\begin{array}{lll}\text { COM50 } & 0.756 & \text { COM52 } \\
0.775 & \\
\text { COM51 } & 0.819 & \\
\end{array}$} & 0.945 & 0.852 \\
\hline Conventional & & \multicolumn{3}{|c|}{$\begin{array}{ll}\text { CL53 0.758 } & \text { CL61 0.606 } \\
\text { CL54 0.743 } & \text { CL62 0.682 } \\
\text { CL55 0.703 } & \text { CL63 0.664 } \\
\text { CL56 0.692 } & \text { CL65 0.689 } \\
\text { CL57 0.787 } & \text { CL66 0.771 } \\
\text { CL58 0.809 } & \text { CL67 0.705 } \\
\text { CL59 0.630 } & \text { CL68 0.758 } \\
\text { CL60 0.730 } & \text { CL70 0.578 }\end{array}$} & 0.951 & 0.521 \\
\hline & $\begin{array}{l}\text { Blue ocean } \\
\text { leadership } \\
\text { style }\end{array}$ & \multicolumn{3}{|c|}{$\begin{array}{lc}\text { Visionary } & 0.731 \\
\text { Contingent reward } & 0.735 \\
\text { Courage } & 0.861 \\
\text { Idealized influences } & 0.771 \\
\text { Inspiration } & 0.761 \\
\text { Intellectual stimulation } & 0.836 \\
\text { Passion } & 0.779 \\
\text { Strategic thinking } & 0.670 \\
\text { Focus } & 0.685 \\
\text { Collaborate } & 0.747 \\
\text { Innovate } & 0.807 \\
\text { Willingness to change } & 0.734 \\
\text { Communication } & 0.852 \\
\text { Conventional } & 0.564 \\
\end{array}$} & 0.984 & 0.510 \\
\hline Intrapersonal & & \multicolumn{3}{|c|}{$\begin{array}{l}\text { INTRA1 } 0.887 \\
\text { INTRA2 } 0.937 \\
\text { INTRA3 } 0.841\end{array}$} & 0.919 & 0.790 \\
\hline Interpersonal & & \multicolumn{3}{|c|}{$\begin{array}{l}\text { INTRE4 } 0.864 \\
\text { INTRE5 } 0.658 \\
\text { INTRE6 } 0.785 \\
\end{array}$} & 0.906 & 0.662 \\
\hline $\begin{array}{c}\text { Stress } \\
\text { management }\end{array}$ & & \multicolumn{3}{|c|}{$\begin{array}{ll}\text { SM9 } & 0.909 \\
\text { SM10 } & 0.793 \\
\text { SM11 } & 0.648 \\
\end{array}$} & 0.831 & 0.625 \\
\hline Adaptability & & \multicolumn{3}{|c|}{$\begin{array}{ll}\text { ADPT12 } & 0.854 \\
\text { ADPT13 } & 0.918 \\
\text { ADPT14 } & 0.865 \\
\end{array}$} & 0.915 & 0.685 \\
\hline General mood & & \multicolumn{3}{|c|}{ GM17 0.903} & 0.965 & 0.752 \\
\hline
\end{tabular}




\begin{tabular}{|l|l|lc|c|c|}
\hline & & GM18 0.932 & GM22 0.934 & & \\
& & GM19 0.849 & GM23 0.914 & & \\
& & GM20 0.764 & GM24 0.881 & & \\
& GM25 0.785 & & & \\
& Emotional & Intrapersonal & 0.790 & 0.975 & 0.633 \\
& intelligence & Interpersonal & 0.736 & & \\
& & Stress management & 0.774 & & \\
& & Adaptability & 0.582 & & \\
& & General mood & 0.782 & & \\
\hline
\end{tabular}

Table 3: Discriminant validity

\begin{tabular}{|l|c|c|}
\hline & $\begin{array}{c}\text { Blue ocean } \\
\text { leadership style }\end{array}$ & $\begin{array}{c}\text { Emotional } \\
\text { intelligence }\end{array}$ \\
\hline Blue ocean leadership style & $\mathbf{0 . 7 1 4}$ & \\
\hline Emotional intelligence & 0.609 & $\mathbf{0 . 7 7 5}$ \\
\hline
\end{tabular}

**Note. The diagonal values in bold signify the average variance extracted (AVE) while the other entries signify the squared correlations.

\subsection{Structural model analysis}

Structural model is evaluated based on bootstrapping for hypothesis testing, significance of the path coefficients, explained variance (value of R2), and test for predicative relevance (Q2) (Roldán \& Sánchez-Franco, 2012). Table 4 below explain the relationship between blue ocean leadership styles and emotional intelligence. Bootstrapping is specifically, used to obtain the significance levels of the path coefficients through tstatistics (Ringle, Sarstedt, \& Mooi, 2010). The result in Table 3 below, accept the hypothesis, $\mathrm{H} 1$ there is a siginificant influences between blue ocean leadership style and emotional intelligence, with (t-value: $5.154 * *$, p-value $<0.01$ ). The result is similar with previous findings by (Clarke, 2010; Harms \& Crede, 2010; Hunt \& Fitzgerald, 2013; Lam \& O'Higgins, 2012; Lindebaum \& Cartwright, 2010; Wang \& Huang, 2009; Weinberger, 2009), which indicates the important of leadership on emotional intelligence. (Cohen, 1988) suggested that the $\mathrm{R}^{2}$ value, is considered substantial when it is 0.26 , moderate when the value is 0.13 and weak when it is 0.02 . Results confirmed as substantial with R2 (0.371) values in our study, as shown in Table 4 . Next, $Q^{2}$ values will be calculated using the blindfolding procedure to generate the cross-validate communality and cross-validated redundancy, in order to assess the quality of the model. Chin (2010) recommended that the communality and redundancy Q-square indices must be greater than zero, for the model to have predictive relevance. As shown in Table 4, the value for $\mathrm{Q}^{2}=1-\mathrm{SSE} / \mathrm{SSO}$ of 0.462 which is more than 0 suggesting that the model has sufficient predictive blindfolding procedure obtained. Thus, the result provide the support that the variables use in this study are adequately predicting the independent variable. 
Table 4: Bootstrapping result

\begin{tabular}{|c|c|c|c|c|c|c|c|}
\hline & Hypothesis & $\begin{array}{c}\text { Standard } \\
\text { data }\end{array}$ & $\begin{array}{c}\text { Standard } \\
\text { error }\end{array}$ & t-value & Decision & $\mathbf{R}^{2}$ & $\mathbf{Q}^{\mathbf{2}}$ \\
\hline $\mathrm{H}$ & $\begin{array}{c}\text { Blue ocean } \\
\text { leadership -> } \\
\text { Emotional } \\
\text { intelligence }\end{array}$ & 0.609 & 0.604 & $5.154^{* *}$ & Accepted & 0.371 & 0.462 \\
\hline
\end{tabular}

\subsection{Importance Performance Matrix Analysis (IPMA)}

Importance-performance matrix (IPMA) was carried out became carried out with a view to identify the possible areas that want to be addressed and identified areas with excessive importance and low overall performance (Ahmad \& Afthanorhan, 2014; Schloderer, Sarstedt, \& Ringle, 2014). The target construct of this study is blue ocean leadership style and emotional intelligence. Figure 2 and 3 below, schematically shows the IPMA results of the target variable. As present in Table 5 for blue ocean leadership, strategic thinking have the highest importance (0.088). While for emotional intelligence, general mood have the highest importance $(0.4103)$.

From the importance performance matrix result, in order to transforms towards industry 4.0, it is suggested that organization should be focusing on strategic thinking and general mood. Strategic thinking would be important as by employing it would enables analysis, exploration, understanding and defining a complex situation (Kazmi, Naarananoja, \& Wartsila, 2016). general mood, it includes skills such as the generation and belief of happiness and optimism, inclusive of the capacity to be satisfied with and enjoy one's life, to appearance on the brighter facet, and to keep a fine attitude within the face of adversity (Bar-On \& Parker, 2000). This skills would help leader in managing their emotions, in order to adapt with changes which would occur in the organisation during the transformation towards industry 4.0.

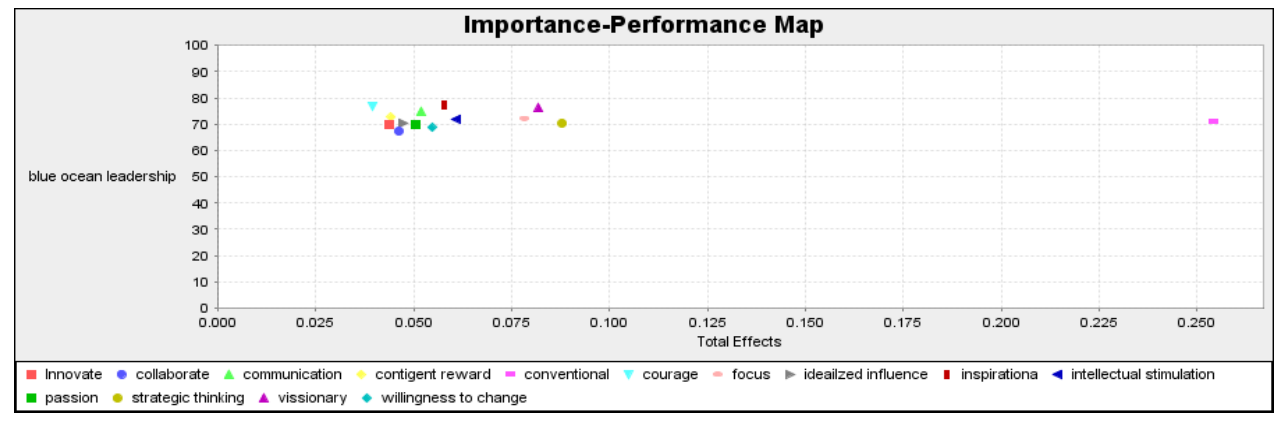

Figure 2: Importance perfromance map (blue ocean leadership style) 


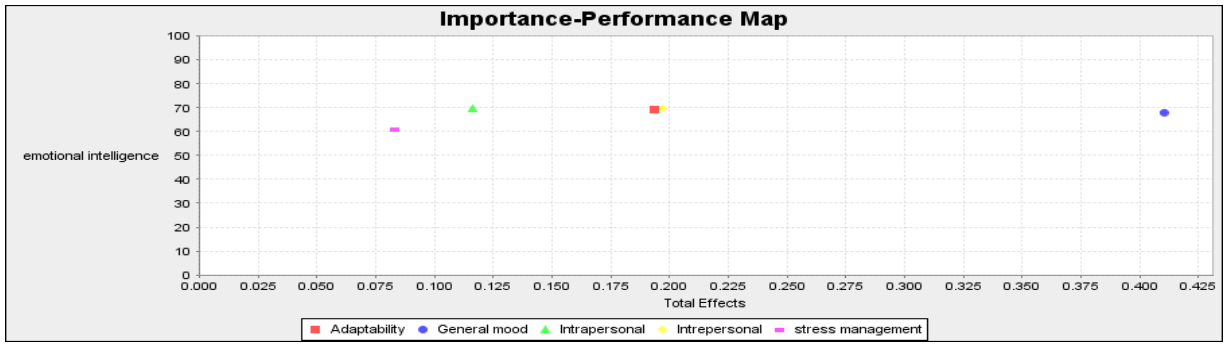

Figure 3: Importance performance map (emotional intelligence)

Table 5: IPMA result for blue ocean leadership style and emotional intelligence

\begin{tabular}{|l|l|l|}
\hline \multicolumn{1}{|c|}{ Variables } & \multicolumn{1}{c|}{ Importance } & Performance \\
\hline \multicolumn{2}{|c|}{ Blue ocean leadership style } \\
\hline Visionary & 0.082 & 76.154 \\
\hline Contigent reward & 0.044 & 72.623 \\
\hline Courage & 0.040 & 76.803 \\
\hline Idealized influence & 0.047 & 70.429 \\
\hline Inspiration & 0.058 & $\mathbf{7 7 . 0 2 7}$ \\
\hline $\begin{array}{l}\text { Intellectual } \\
\text { stimulation }\end{array}$ & 0.061 & 72.040 \\
\hline Passion & 0.050 & 70.040 \\
\hline Strategic thinking & $\mathbf{0 . 0 8 8}$ & 70.342 \\
\hline Focus & 0.078 & 72.178 \\
\hline Collaborate & 0.046 & 67.325 \\
\hline Innovative & 0.044 & 69.609 \\
\hline $\begin{array}{l}\text { Willingness to } \\
\text { change }\end{array}$ & 0.055 & 68.755 \\
\hline Communication & 0.052 & 75.007 \\
\hline Conventional & 0.054 & 70.914 \\
\hline \multicolumn{2}{|l|}{ Emotional intelligence } \\
\hline Intrapersonal & 0.1160 & 69.7410 \\
\hline Interpersonal & 0.1972 & $\mathbf{6 9 . 7 8 5 9}$ \\
\hline Stress management & 0.0828 & 60.9182 \\
\hline Adaptability & 0.1937 & 69.3086 \\
\hline General mood & $\mathbf{0 . 4 1 0 3}$ & 67.9402 \\
\hline \multicolumn{2}{|l|}{} \\
\hline
\end{tabular}

\section{Conclusion}

The current study examine the influences of blue ocean leadership styles on emotional intelligence. The findings confirmed the relationships among both variables and thus, it shows leadership styles do influence emotional intelligence. The overall model R2 was successful in explaining approximately $37.1 \%$, the result shows that the model here is considered substantial in indicating the power of blue ocean leadership styles in explaining emotional intelligence. This shows that the application of emotional intelligence in any organization by a leader plays a vital role to be effective and efficient leader(Batool, 2013). Base from the IPMA analysis, in order to prepare the oranization towards industry 4.0, 
leaders must be specializing in strategic thinking as using strategic thinking allows analysis, exploration, knowledge and defining a complicated scenario and then developing planning actions to attain the best feasible effective effect towards a pre-defined purpose (Kazmi et al., 2016). Next, leader should also be focusing on general mood, as the blue ocean leadership style could raise employee emotion that could motivates them to achieve organizational vision. Further, this study contributes toward new knowledge in the field of leadership, by pointing to the leadership role of accurate attributions, where each attributions can lead towards enhancing leader's emotional intelligence. Future studies could expand the scope and depth of knowledge by undertaking the research in different organization settings, as this study is conducted in the Government Link Companies (GLCs) in Malaysia.

\section{References}

Ahmad, S., \& Afthanorhan, W. M. A. B. W. (2014). The importance-performance matrix analysis in partial least square structural equation modeling (PLS-SEM) with smartpls 2.0 M3. International Journal of Mathematics Research, 3(1), 1.

Alhuraish, I., Robledo, C., \& Kobi, A. (2014). Key Success Factors of Implementing Lean Manufacturing and Six Sigma. Paper presented at the Liverpool (2014): 17th Toulon-Verona Conference" Excellence in Services".

Anand, \& UdayaSuriyan. (2010). Emotional intelligence and its relationship with leadership practices. International Journal of Business and Management, 5(2), 65.

Anderson, \& Gerbing. (1988). Structural equation modeling in practice: A review and recommended two-step approach. Psychological bulletin, 103(3), 411.

Bar-On, R., \& Parker, J. D. A. (2000). BarOn emotional quotient inventory: Youth version: Multi-Health system, Incorporated Toronto, ON, Canada.

Barbuto, \& Burbach. (2006). The emotional intelligence of transformational leaders: A field study of elected officials. The Journal of social psychology, 146(1), 51-64.

Bass, \& Stogdill. (1990). Bass \& Stogdill's handbook of leadership: Theory, research, and managerial applications: Simon and Schuster.

Batool. (2013). Emotional intelligence and effective leadership. Journal of Business Studies Quarterly, 4(3), 84.

Birkinshaw, J., Hamel, G., \& Mol, M. J. (2008). Management innovation. Academy of management review, 33(4), 825-845.

Butler, \& Chinowsky. (2006). Emotional intelligence and leadership behavior in construction executives. Journal of Management in Engineering, 22(3), 119-125.

Chin. (2010). How to write up and report PLS analyses. In Handbook of partial least squares (pp. 655-690): Springer.

Clarke. (2010). Emotional intelligence and its relationship to transformational leadership and key project manager competences. Project Management Journal, 41(2), 5-20.

Cohen. (1988). Statistical power analysis.

Conte, J. M. (2005). A review and critique of emotional intelligence measures. Journal of Organizational Behavior, 26(4), 433-440.

Cross, B., \& Travaglione, A. (2003). The untold story: is the entrepreneur of the 21st century defined by emotional intelligence? The International Journal of Organizational Analysis, 11(3), 221-228.

Du Toit, \& Jane, A. (2014). Emotional intelligence and leadership in a South African financial services institution.

Engelbertink, D., \& Woudstra, S. (2017). Managing the influences and risks of Industry 4.0. University of Twente, 
Feng, Y. (2016). Future Development Possibilities of Talent Management under the Influence of 'Industry 4.0'.

Fornell, C., \& Larcker, D. F. (1981). Evaluating structural equation models with unobservable variables and measurement error. Journal of marketing research, 3950 .

Gardner, \& Stough. (2002). Examining the relationship between leadership and emotional intelligence in senior level managers. Leadership \& Organization Development Journal, 23(2), 68-78.

Goleman. (1998). Working with Emotional Intelligence. Bloomsbury. In: London.

Group, M. (2017). "The Skills Revolution: Digitization and Why People and Talent Matter", . http: //www.manpowergroup.co.uk/wp-content/uploads/2017/01/theskills-revolution_lo.pdf

Hair, Hult, \& Ringle. (2014). A Primer on Partial Least Squares Structural Equation Modeling (PLS-SEM). In: Thousand Oaks (CA): Sage Publications.

Harms, \& Crede. (2010). Emotional intelligence and transformational and transactional leadership: A meta-analysis. Journal of Leadership \& Organizational Studies, 17(1), 5-17.

Hopkins, M. M., O'Neil, D. A., \& Williams, H. W. (2007). Emotional intelligence and board governance: Leadership lessons from the public sector. Journal of Managerial Psychology, 22(7), 683-700.

Hunt, \& Fitzgerald. (2013). The relationship between emotional intelligence and transformational leadership: An investigation and review of competing claims in the literature. American International Journal of Social Science, 2(8), 30-38.

Johnson, B., \& Christensen, L. (2008). Educational research: Quantitative, qualitative, and mixed approaches: Sage.

Kazmi, S. A. Z., Naarananoja, M., \& Wartsila, J. K. (2016). Integrating Strategic Thinking and Transformational Leadership for NPD Idea Support Process. Procedia-Social and Behavioral Sciences, 229, 387-397.

Kim, \& Mauborgne. (2014). Blue Ocean Strategy, Expanded Edition: How to Create Uncontested Market Space and Make the Competition Irrelevant: Harvard Business Review Press.

Kim, \& Mauborgne. (2017). Blue Ocean Leadership (Harvard Business Review Classics): Harvard Business Review Press.

Lam, \& O'Higgins. (2012). Enhancing employee outcomes: The interrelated influences of managers' emotional intelligence and leadership style. Leadership and Organization Development Journal, 33(2), 149-174.

Laohavichien, T., Fredendall, L. D., \& Cantrell, R. S. (2009). The effects of transformational and transactional leadership on quality improvement. The Quality Management Journal, 16(2), 7.

Latham, J. R. (2014). Leadership for quality and innovation: Challenges, theories, and a framework for future research. Quality Management Journal, 21 (1), 5.

Lee, Y. S. (2014). Emotional intelligence and job performance: evidence of private higher educational institutions in malaysia

dissertation universiti tunku Aabdul rahman.

Lindebaum, D., \& Cartwright, S. (2010). A critical examination of the relationship between emotional intelligence and transformational leadership. Journal of Management Studies, 47(7), 1317-1342.

López-Domínguez, M., Enache, M., Sallan, J. M., \& Simo, P. (2013). Transformational leadership as an antecedent of change-oriented organizational citizenship behavior. Journal of business research, 66(10), 2147-2152. 
Mageswari, S. U., Sivasubramanian, C., \& Dath, T. S. (2015). Knowledge management enablers, processes and innovation in small manufacturing firms: a structural equation modeling approach. IUP Journal of Knowledge Management, 13(1), 33.

Nahavandi, A. (2006). Teaching leadership to first-year students in a learning community. Journal of Leadership Education, 5(2), 14-27.

Noruzy, A., Dalfard, V. M., Azhdari, B., Nazari-Shirkouhi, S., \& Rezazadeh, A. (2013). Relations between transformational leadership, organizational learning, knowledge management, organizational innovation, and organizational performance: an empirical investigation of manufacturing firms. The International Journal of Advanced Manufacturing Technology, 1-13.

Nunnally, \& Bernstein. (1994). The assessment of reliability. Psychometric theory, 3(1), 248-292.

Pisano, G. P., \& Teece, D. J. (2007). How to capture value from innovation: Shaping intellectual property and industry architecture. California management review, 50(1), 278-296.

Poksinska, B., Swartling, D., \& Drotz, E. (2013). The daily work of Lean leaders-lessons from manufacturing and healthcare. Total Quality Management \& Business Excellence, 24(7-8), 886-898.

Puteri Aishah, Abd Rahim, Ismail, \& Mariatul Shima. (2015). Exploring the Symbiotic Relationship between Emotional Intelligence and

Transformational Leadership. Journal of applied science and research, 11(18), 8-13.

Radhakrishnan, A., \& UdayaSuriyan, G. (2010). Emotional intelligence and its relationship with leadership practices. International Journal of Business and Management, $5(2), 65$.

Rajah, R., Song, Z., \& Arvey, R. D. (2011). Emotionality and leadership: Taking stock of the past decade of research. The leadership quarterly, 22(6), 1107-1119.

Rehman. (2012). Transformational leadership style as predictor of decision making styles: moderating role of emotional intelligence. Pakistan Journal of Commerce and Social Sciences, 6(2).

Riaz, A., \& Haider, M. H. (2010). Role of transformational and transactional leadership on job satisfaction and career satisfaction. Business and Economic Horizons, 1(1), 2938 .

Ringle, C. M., Sarstedt, M., \& Mooi, E. A. (2010). Response-based segmentation using finite mixture partial least squares. Paper presented at the Data Mining.

Roldán, J. L., \& Sánchez-Franco, M. J. (2012). Variance-based structural equation modeling: guidelines for using partial least squares. Research methodologies, innovations and philosophies in software systems engineering and information systems, 193.

Rosete, D., \& Ciarrochi, J. (2005). Emotional intelligence and its relationship to workplace performance outcomes of leadership effectiveness. Leadership \& Organization Development Journal, 26(5), 388-399.

Schloderer, M. P., Sarstedt, M., \& Ringle, C. M. (2014). The relevance of reputation in the nonprofit sector: The moderating effect of socio-demographic characteristics. International Journal of Nonprofit and Voluntary Sector Marketing, 19(2), 110126.

Schwab, K. (2017). The fourth industrial revolution: Crown Business.

Singh, \& Krishnan. (2008). Self-sacrifice and transformational leadership: mediating role of altruism. Leadership \& Organization Development Journal, 29(3), 261-274.

Sy, T., Tram, S., \& O'Hara, L. A. (2006). Relation of employee and manager emotional intelligence to job satisfaction and performance. Journal of Vocational Behavior, 68(3), 461-473. 
Tunçer, P. (2011). Organizational change and leadership. Journal of Court of Accounts, 80, 57-83.

Van den Hurk, A. F., Hall-Mendelin, S., Johansen, C. A., Warrilow, D., \& Ritchie, S. A. (2012). Evolution of mosquito-based arbovirus surveillance systems in Australia. BioMed Research International, 2012.

Wan Noordiana, W. H., Salina, D., \& Nur Liyana, B. (2016). Blue ocean leadership determinants. International Journal of Management and Applied Science, 2(1), 7275.

Wang, \& Huang. (2009). The relationship of transformational leadership with group cohesiveness and emotional intelligence. Social Behavior and Personality: an international journal, 37(3), 379-392.

Weinberger. (2009). Emotional intelligence, leadership style, and perceived leadership effectiveness. Advances in Developing Human Resources, 11(6), 747-772.

Weinmann, C. (2017). Responding to opportunities provided by General Purpose Technologies: Industry 4.0 in Finland.

Wong, C.-S., \& Law, K. S. (2002). The effects of leader and follower emotional intelligence on performance and attitude: An exploratory study. The leadership quarterly, 13(3), 243-274. 